DOI: $10.15193 /$ zntj/2017/112/205

\title{
AGNIESZKA KAWECKA, AGNIESZKA CHOLEWA-WÓJCIK \\ JAKOŚĆ OPAKOWANIA JAKO DETERMINANTA BEZPIECZEŃSTWA ŻYWNOŚCI W KONTEKŚCIE WYMAGAŃ SPOŁECZNYCH KONSUMENTÓW
}

\author{
Streszczenie
}

Trendy konsumpcyjne odnoszące się do jakości produktów spożywczych i opakowań są ściśle związane z wymaganiami, jakie względem nich zgłaszają konsumenci. Wymagania społeczne konsumentów w odniesieniu do opakowań można pogrupować w podstawowe obszary, do których należą: bezpieczeństwo, przedłużenie trwałości produktu poprzez właściwy dobór opakowania, komunikacja z konsumentem, wygoda i funkcjonalność oraz ograniczenie negatywnego oddziaływania na środowisko naturalne. Bezpieczeństwo stanowi jedną z podstawowych potrzeb człowieka, która powinna być zaspokajana także przez opakowania. Opakowania bezpieczne powinny charakteryzować się przede wszystkim odpowiednim stanem sanitarno-higienicznym, niestanowiącym zagrożenia dla zapakowanego produktu spożywczego, ale też powinny zapewniać bezpieczne użytkowanie opakowania. Opakowania muszą się ponadto charakteryzować stabilnymi parametrami użytkowymi o określonej wartości, gdyż od nich zależy ochrona zapakowanych towarów.

Celem niniejszej pracy było określenie wymagań społecznych konsumentów w odniesieniu do bezpieczeństwa zapakowanej żywności jako czynnika w istotny sposób wpływającego na jakość opakowań.

Przedstawione wyniki badań dotyczące analizy potrzeb i wymagań stawianych opakowaniom do żywności pozwoliły na określenie hierarchii ważności wymagań społecznych konsumentów względem opakowań do żywności. Wykazano, że dla 90 \% konsumentów bezpieczeństwo jest najważniejszym z wymagań społecznych stawianych opakowaniom. Do grup cech bardzo ważnych $75 \%$ konsumentów zaliczyło bezpieczeństwo użytkowania. Zachowanie ilości i jakości zawartości podczas przechowywania i użytkowania, obecność zabezpieczeń przed niepożądanym otwarciem oraz obecność informacji wpływających na bezpieczeństwo użytkownika są dla $83 \%$ konsumentów cechami ważnymi. Z kolei $60 \%$ konsumentów przypisało średnią ważność cechom, takim jak: obecność zabezpieczeń gwarantujących pierwsze użycie oraz bezpieczeństwo przy manipulacjach. Natomiast dla $54 \%$ respondentów najmniej istotna ze wszystkich analizowanych cech opakowań była cecha związana z odpornością opakowania na czynniki mikroklimatyczne, biotyczne i mechaniczne.

Dr inż. A. Kawecka, dr inż. A. Cholewa-Wójcik, Katedra Opakowalnictwa Towarów, Wydz. Towaroznawstwa, Uniwersytet Ekonomiczny w Krakowie, ul. Rakowicka 27, 31-510 Kraków.

Kontakt: agnieszka.kawecka@uek.krakow.pl 
Słowa kluczowe: jakość opakowań, bezpieczeństwo żywności, wymagania społeczne konsumentów, opakowania do żywności

\section{Wprowadzenie}

Współczesny, świadomy konsument ma sprecyzowane oczekiwania względem jakości produktów spożywczych i ich opakowań. Oczekiwania te wynikają z trendów rynkowych, które w sposób istotny oddziałują na rynek dóbr konsumpcyjny, a przez to na oferowane towary. Wyrazem tego są zmiany struktury konsumpcji i wzrost zapotrzebowania na produkty spożywcze oraz ich opakowania, które będą w wysokim stopniu dostosowane do wymagań konsumentów. Taka sytuacja rynkowa wymusza na producentach opakowań adaptację do zmieniających się warunków otoczenia. Ze względu na rosnącą świadomość konsumentów dotyczącą istnienia zagrożeń związanych z żywnością, do których zaliczyć można m.in. zafałszowania żywności, bioterroryzm itp., zapewnienie bezpieczeństwa zapakowanej żywności jest priorytetowym działaniem wszystkich podmiotów łańcucha żywnościowego.

Celem pracy było określenie wymagań społecznych konsumentów w odniesieniu do bezpieczeństwa zapakowanej żywności jako determinanty jakości opakowań.

\section{Wymagania spoleczne konsumentów względem opakowań żywności}

Problem oczekiwań konsumentów względem opakowań żywności występujących w ofercie rynkowej był przedmiotem licznych badań $[2,3,6-8,10,15,18$ - 20, 22, 23]. W pracach tych brakuje jednak informacji dotyczących analizy stopnia zaspokojenia wymagań społecznych konsumentów przez opakowania żywności. Ponadto w literaturze przedmiotu nie występuje definicja wymagań społecznych w odniesieniu do opakowań. Na podstawie definicji wymagań pochodzącej ze Słownika języka polskiego [16] zaproponowano własną definicję terminu wymagań społecznych wobec opakowań. Zdefiniowano je jako: warunek lub zespół warunków, które musi spełniać opakowanie, aby odpowiadać cechom fizycznym i psychicznym człowieka.

Mając na uwadze podstawy opakowalnictwa oraz koncepcję zaproponowaną przez Bix i wsp. [1], zgodnie z którą społeczne wymagania są ściśle skorelowane z potrzebami konsumentów dotyczącymi opakowań, podjęto próbę zestawienia wymagań społecznych współczesnego konsumenta względem opakowań do żywności [1]. Należą do nich: bezpieczeństwo, przedłużanie trwałości produktu poprzez właściwy dobór opakowania, komunikacja z konsumentem, wygoda i funkcjonalność oraz ograniczenie negatywnego oddziaływania na środowisko naturalne (rys. 1). 


\section{Bezpieczeństwo/Safety}

Dobór opakowania do produktu/

Selection of packaging for product

Komunikacja z konsumentem/

Communication with consumer

Wygoda i funkcjonalność/

Convenience and functionality

Zmniejszenie negatywnego oddziaływania na środowisko/

Reduction of negative impact on the environment

Rys. 1. Wymagania społeczne konsumentów w odniesieniu do opakowań

Fig. 1. Social requirements of consumers on packaging

Źródło: opracowanie własne / Source: the authors' own study

Uwzględnienie wymagań konsumenta wymusza wprowadzanie na rynek opakowań, w których nie występuje niepożądana interakcja pomiędzy opakowaniem i produktem oraz zachowana jest właściwa ilość i jakość zawartości opakowania. Opakowania uwzględniające wymagania konsumenta to również takie, które gwarantują bezpieczeństwo, właściwą komunikację oraz spełnienie wymagań prawnych [5, 11]. W zakresie opakowań do żywności najistotniejsze są wymagania społeczne związane $\mathrm{z}$ bezpieczeństwem i odpowiednim doborem opakowania do produktu warunkującym przedłużenie trwałości żywności $[3,9,12,21]$.

\section{Bezpieczeństwo stosowania opakowań do żywności}

Potrzeba poczucia bezpieczeństwa, jako jedna z podstawowych potrzeb człowieka, powinna być zaspokajana także przez opakowania. Zgodnie z definicją zaproponowaną przez Lisińską-Kuśnierz [11], bezpieczne opakowanie to „opakowanie, które w zwykłych lub innych, dających się w sposób uzasadniony przewidzieć, warunkach jego użytkowania, $\mathrm{z}$ uwzględnieniem czasu korzystania $\mathrm{z}$ opakowania, a także w zależności od rodzaju opakowania oraz od rodzaju pakowanego produktu, nie stwarza żadnego zagrożenia dla konsumenta lub stwarza znikome zagrożenie dające się pogodzić z jego zwykłym użytkowaniem i uwzględniające wysoki poziom wymagań dotyczących ochrony zdrowia i życia ludzi”. 
Bezpieczeństwo opakowań charakteryzowane jest przez atrybuty techniczne materiałów opakowaniowych, opakowań jednostkowych, opakowań zbiorczych oraz dokumentów towarzyszących przepływowi w łańcuchu dostaw, a także atrybuty systemowe. Wśród technicznych atrybutów bezpieczeństwa dotyczących materiałów opakowaniowych i opakowań jednostkowych wyróżnia się: odpowiedni skład chemiczny, zachowanie limitów migracji globalnej i specyficznej, zachowanie dopuszczalnego poziomu zanieczyszczenia powierzchni mikroorganizmami, brak ciał obcych, odpowiednie cechy sensoryczne oraz właściwy stan opakowania jednostkowego. Z kolei atrybuty systemowe związane są z uwarunkowaniami minimalizacji występowania zagrożeń bezpieczeństwa w łańcuchu dostaw opakowań [14]. Bezpieczeństwo opakowań należy więc rozumieć w szerokim zakresie, w obrębie którego można wydzielić dwa podstawowe obszary:

- bezpieczeństwo higieniczno-sanitarne,

- bezpieczeństwo użytkowania.

Bezpieczeństwo higieniczno-sanitarne dotyczy przede wszystkim odpowiedniego składu surowcowego materiału opakowaniowego, w szczególności stosowania do produkcji jedynie prawnie dopuszczonych surowców i substancji. Ściśle związane jest także $\mathrm{z}$ transferem substancji z materiału opakowaniowego do zapakowanej żywności, czyli z migracją, która powinna być na minimalnym poziomie i nie powinna powodować zmian w składzie żywności. Ponadto uwzględniać należy cechy sensoryczne materiałów opakowaniowych i opakowań tak, aby nie prowadziły one do zmian cech sensorycznych opakowanego produktu. Bezpieczeństwo higieniczne dotyczy również odpowiedniego stanu mikrobiologicznego opakowań, które mogą być źródłem zanieczyszczenia mikrobiologicznego zapakowanych towarów. Wymagania dotyczące bezpieczeństwa opakowań przeznaczonych do kontaktu z żywnością są uregulowane w aktach prawnych. Podstawowe wymagania odnoszące się do materiałów wchodzących w kontakt z żywnością zawarto w Rozporządzeniu (WE) nr 1935/2004 Parlamentu Europejskiego i Rady z dnia 27 października 2004 r. $w$ sprawie materiałów $i$ wyrobów przeznaczonych do kontaktu z żywnościa, natomiast uregulowania dotyczące materiałów i wyrobów z tworzyw sztucznych - w Rozporządzeniu Komisji (UE) nr 10/2011 z dnia 14 stycznia 2011 r. w sprawie materiałów $i$ wyrobów z tworzyw sztucznych przeznaczonych do kontaktu z żywnościa.

Bezpieczeństwo użytkowania warunkowane jest z kolei brakiem wad o krytycznym znaczeniu dla bezpieczeństwa użytkowania i brakiem manipulacji opakowaniem. Zagrożenie bezpieczeństwa mogą u konsumenta powodować: niewłaściwa konstrukcja opakowania (np. ostre elementy zamknięcia, brak stabilności opakowania podczas użytkowania), trudność otwarcia i ponownego zamknięcia, niewłaściwe zabezpieczenie przed niepożądanym otwarciem przez dzieci, wady powierzchni mogące spowodować skaleczenie podczas użytkowania, brak elementów identyfikujących zawartość 
oraz brak na opakowaniu informacji związanych z bezpieczeństwem użytkowania produktu (termin przydatności do spożycia, skład, a przede wszystkim informacja o obecności alergenów, sposób przygotowania żywności, warunki przechowywania oraz różnego typu ostrzeżenia). Wymagania w zakresie przekazywania tego typu informacji zawarte są w Rozporządzeniu Parlamentu Europejskiego i Rady (UE) nr 1169/2011 z dnia 25 października 2011 r. $w$ sprawie przekazywania konsumentom informacji na temat żywności.

Zagrożenie dla bezpieczeństwa żywności może być również związane z brakiem gwarancji nienaruszalności opakowania oraz oryginalności zapakowanego produktu. Coraz szersze zastosowanie znajdują zatem zabezpieczenia w postaci tzw. gwarancji pierwszego otwarcia. Celem ich stosowania jest dostarczenie konsumentom dowodu, że opakowanie nie zostało naruszone, a zapakowany produkt jest oryginalny [11].

Bezpieczeństwo jest dla konsumentów priorytetowym wymaganiem stawianym żywności i jej opakowaniom. Jednocześnie bezpieczeństwo opakowań stanowi jeden z podstawowych mierników ich jakości.

\section{Jakość opakowań jako element zapewnienia ochrony zapakowanego produktu spożywczego}

Jakość wyrobów, w tym opakowań, zgodnie z normą PN-EN ISO 9000:2015-10 [16] definiowana jest jako: „stopień, w jakim zbiór inherentnych właściwości obiektu spełnia wymagania" [16]. Jakość opakowań warunkowana jest przez takie czynniki jak: jakość surowca do produkcji materiału opakowaniowego, właściwe prowadzenie procesu produkcji, odpowiednie warunki podczas przechowywania, transportu i dystrybucji w przedsiębiorstwach. Jakość opakowań można rozumieć jako niezbędne cechy i właściwości techniczne charakteryzujące jego wartość użytkową (m.in. barierowość materiału opakowaniowego, wytrzymałość mechaniczna i szczelność opakowania). Z drugiej strony jakość opakowań można analizować ze względu na wymagania społeczne użytkowników, które są ściśle związane z trendami społecznymi wpływającymi na konsumpcję. Zapewnienie wysokiej jakości opakowania wymaga uwzględnienia zarówno spełnienia wymagań technicznych, jak i wymagań użytkownika.

Opakowania do żywności powinny mieć odpowiednią wartość użytkową rozumianą jako stopień, w jakim zbiór właściwości opakowania spełnia wymagania związane z jego użytkowaniem. Biorąc za kryterium podziału użyteczność wyrobów (w tym opakowań) spośród właściwości charakteryzujących wartość użytkową należy wymienić m.in. cechy techniczne związane z właściwościami wyrobu (użytkowe) oraz związane z dyspozycyjnością (np. niezawodność). W przypadku opakowań duże znaczenie mają ich cechy techniczne. Opakowania muszą się bowiem charakteryzować stabilnymi parametrami użytkowymi o określonej wartości, gdyż przede wszystkim od 
nich zależy ochrona jakości zapakowanych towarów. Problem ten nabiera szczególnego znaczenia w przypadku produktów spożywczych, dla których niezwykle istotne jest zabezpieczenie przed różnego rodzaju zagrożeniami pojawiającymi się podczas przechowywania i użytkowania oraz zabezpieczenie przed zanieczyszczeniem mikrobiologicznym. Ochrona zapakowanego produktu powinna w szczególności obejmować zabezpieczenie przed [3]:

- niszczącym działaniem przede wszystkim czynników klimatycznych, biotycznych i mechanicznych,

- ubytkami ilościowymi,

- zmianami kształtu, konsystencji, smakowitości,

- zmianami lub utratą cech użytkowych produktu.

Zachowanie właściwej ilości i jakości zawartości jest możliwe poprzez właściwy dobór materiału opakowaniowego, rodzaju opakowania oraz systemu pakowania do konkretnego rodzaju produktu spożywczego. Trwałość żywności można przedłużyć przez pakowanie jej w modyfikowanej atmosferze (MAP) oraz stosowanie opakowań aktywnych. Zadaniem tych rozwiązań jest przedłużenie okresu przydatności żywności do sprzedaży i spożycia lub poprawa stanu opakowanej żywności [21].

Ocena wartości użytkowej w aspekcie cech związanych z dyspozycyjnością opakowań może natomiast przebiegać na podstawie analizy ich niezawodności, rozumianej jako zdolność do spełnienia stawianych im wymagań w określonym czasie i określonych warunkach.

Podczas analizy jakości opakowań z uwzględnieniem wymagań społecznych skorelowanych z trendami konsumpcyjnymi należy zwrócić uwagę na coraz większe znaczenie wygody użytkowania opakowań, także w różnych warunkach użytkowania czy zapewnienie ochrony produktu w różnych warunkach przechowywania. Opakowanie powinno być dobrane $\mathrm{w}$ taki sposób, aby korzystnie oddziaływało na zapakowaną żywność w całym łańcuchu logistycznym. Stosowanie opakowań właściwej jakości jest nie tylko działaniem mającym na celu spełnienie potrzeb i oczekiwań konsumentów, lecz także stanowi rozwiązanie problemu marnotrawstwa żywności jako powszechnego zjawiska występującego na wszystkich etapach łańcucha żywnościowego [4].

\section{Metody badań}

W celu przeprowadzenia analizy wymagań społecznych konsumentów w odniesieniu do bezpieczeństwa zapakowanej żywności jako determinanty jakości opakowań przeprowadzono badania ankietowe. Zakres badań obejmował:

- określenie ważności wymagań społecznych konsumentów względem opakowań do żywności, 
- wskazanie cech i elementów opakowań do żywności istotnych pod względem wymagań konsumentów związanych z bezpieczeństwem.

Do badań, które przeprowadzono w 2014 roku, użyto kwestionariusza zawierającego pytania jednokrotnego i wielokrotnego wyboru oraz zadania związane z porządkowaniem, które zostały sformułowane na podstawie wcześniej przeprowadzonych badań pilotażowych. W badaniu ankietowym wzięło udział 200 respondentów, których dobór był przypadkowy. Ich profil socjodemograficzny przedstawiono w tab. 1 .

Tabela 1. Profil socjodemograficzny badanej populacji

Table 1. Sociodemographic profile of population studied

\begin{tabular}{|c|c|c|c|}
\hline \multicolumn{2}{|c|}{$\begin{array}{l}\text { Kryterium socjodemograficzne } \\
\text { Sociodemographic criterion }\end{array}$} & $\begin{array}{c}\text { Liczba } \\
\text { Quantity }\end{array}$ & $\begin{array}{c}\text { Udział / Share } \\
{[\%]}\end{array}$ \\
\hline \multirow{2}{*}{$\begin{array}{l}\text { Płeć } \\
\text { Gender }\end{array}$} & Kobiety / Women & 116 & 58 \\
\hline & Mężczyźni / Men & 84 & 42 \\
\hline \multirow{6}{*}{$\begin{array}{l}\text { Wiek respondentów } \\
\text { Age of respondents }\end{array}$} & do 25 lat / under 25 & 80 & 40 \\
\hline & $26-35$ & 38 & 19 \\
\hline & $36-45$ & 32 & 16 \\
\hline & $46-55$ & 26 & 13 \\
\hline & $56-65$ & 14 & 7 \\
\hline & powyżej 65 / above 65 & 10 & 5 \\
\hline \multirow{6}{*}{$\begin{array}{l}\text { Miejsce zamieszkania } \\
\text { Place of residence }\end{array}$} & Wieś / Village & 44 & 22 \\
\hline & $\begin{array}{l}\text { Miasto do } 50 \text { tys. mieszkańców } \\
\text { City up to } 50 \text { thous. inhabitants }\end{array}$ & 18 & 9 \\
\hline & $50-100$ tys. / $50-100$ thous. & 22 & 11 \\
\hline & $100-250$ tys. / $100-250$ thous. & 10 & 5 \\
\hline & $250-500$ tys. / $250-500$ thous. & 14 & 7 \\
\hline & pow. 500 tys. / above 500 thous. & 92 & 46 \\
\hline
\end{tabular}

Źródło: opracowanie własne / Source: the authors' own study.

Pierwszym etapem badań była analiza ważności wymagań społecznych względem opakowań do żywności. W celu określenia ważności ww. wymagań zastosowano szczegółową identyfikację rang kryteriów z wykorzystaniem 5-stopniowej skali rang (w której 1 oznaczało brak ważności, a 5 oznaczało bardzo dużą ważność).

Drugim etapem badań było wskazanie, istotnych dla respondentów, cech i elementów opakowań związanych z bezpieczeństwem. W celu oceny ważności poszczególnych cech opakowań do żywności zastosowano 5-punktową skalę ocen, w której 1 - oznaczało brak ważności, 2 - bardzo małą ważność, 3 - małą ważność, 4 - średnią ważność, 5 - dużą ważność. Liczono średnią arytmetyczną ze wszystkich uzyskanych ocen, a także wyliczano udział respondentów wskazujących każdą odpowiedź. 


\section{Wyniki i ich omówienie}

Analiza uzyskanych wyników jednoznacznie wykazała, że dla 90 \% respondentów bezpieczeństwo było najważniejszym wymaganiem społecznym stawianym opakowaniom. Wśród uczestników badania zdecydowana większość (177 ankietowanych stanowiących $88 \%$ ) to konsumenci, dla których spełnienie wymagań związanych z bezpieczeństwem opakowań do żywności było bardzo ważne (53 \%) i ważne (35\%). Podkreślić należy, że żaden z respondentów nie wskazał na brak ważności cech związanych $\mathrm{z}$ bezpieczeństwem. W grupie badanych zwracających uwagę na cechy opakowania związane $\mathrm{z}$ aspektem bezpieczeństwa znaleźli się przede wszystkim konsumenci w dwóch przedziałach wiekowych: 26 - 35 lat (106 osób) i 36 - 45 lat (70 osób).

Tabela 2. Ważność cech i elementów opakowań do żywności uwzględniających wymagania konsumentów związane $\mathrm{z}$ bezpieczeństwem

Table 2. Importance of characteristics and elements of food packaging compatible with consumer requirements on safety

\begin{tabular}{||l|c||}
\hline \multicolumn{1}{|c|}{$\begin{array}{c}\text { Cechy i elementy opakowania związane z bezpieczeństwem opakowania } \\
\text { i zapakowanego produktu }\end{array}$} & $\begin{array}{c}\text { Ważność cechy } \\
\text { Importance of } \\
\text { feature } \\
\text { [pkt / points] }\end{array}$ \\
\hline $\begin{array}{l}\text { Brak interakcji składników materiału opakowaniowego z produktem } \\
\text { No interaction between ingredients of packaging material and product }\end{array}$ & 4,8 \\
\hline $\begin{array}{l}\text { Zachowanie ilości i jakości zawartości podczas przechowywania i użytkowania } \\
\text { Maintaining quantity and quality of the contents during storage and use }\end{array}$ & 4,4 \\
\hline $\begin{array}{l}\text { Odporność opakowania na zagrożenia mikroklimatyczne, biotyczne i mechaniczne } \\
\text { Packaging resistance to microclimatic, biotic and mechanical exposures }\end{array}$ & 3,5 \\
\hline $\begin{array}{l}\text { Obecność zabezpieczeń gwarantujących pierwsze użycie } \\
\text { Safeguards are present to guarantee that product be used for the first time }\end{array}$ & 4,2 \\
\hline $\begin{array}{l}\text { Obecność zabezpieczeń przed niepożądanym otwarciem } \\
\text { Protection against unwanted opening is present }\end{array}$ & 4,4 \\
\hline $\begin{array}{l}\text { Obecność informacji wpływających na bezpieczeństwo użytkownika (termin przy- } \\
\text { datności do spożycia, skład, a przede wszystkim informacja o obecności alergenów, } \\
\text { sposób przygotowania żywności, warunki przechowywania oraz różnego typu } \\
\text { ostrzeżenia) / Information are present that impact user safety (shelf life, composi- } \\
\text { tion, and, above all, information on occurrence of allergens, method of preparing } \\
\text { food, storage conditions, and various warnings) }\end{array}$ & 4,4 \\
\hline $\begin{array}{l}\text { Bezpieczeństwo użytkowania (brak wad typu ostre krawędzie) } \\
\text { Safety of use (no defects such as sharp edges) }\end{array}$ & \\
\hline $\begin{array}{l}\text { Bezpieczeństwo przy manipulacjach (np. podczas przenoszenia, układania) } \\
\text { Safety while handling (eg. during transporting, arraying) }\end{array}$ & 4,6 \\
\hline \hline
\end{tabular}

Źródło: badania własne / Source: the authors' own study. 
W grupie tej dominowały przede wszystkim kobiety (68\%) oraz osoby mieszkające w mieście powyżej 500 tys. mieszkańców oraz w mieście od 250 - 500 tys. mieszkańców (łącznie 95 osób).

Wyniki drugiego etapu badań w postaci średnich ocen przedstawiono w tab. 2 .

Wykazano, że spośród cech opakowań do żywności związanych z bezpieczeństwem dla $70 \%$ ankietowanych najistotniejszą cechą był brak interakcji składników materiału opakowaniowego z produktem $(4,8 \mathrm{pkt}) .75 \%$ respondentów przypisało wysokie wskazania $(4,6 \mathrm{pkt})$ cechom opakowania związanym $\mathrm{z}$ bezpieczeństwem użytkowania. Natomiast 166 badanych (83\%) przypisało dużą ważność $(4,4$ pkt) takim cechom, jak: zachowanie ilości i jakości zawartości podczas przechowywania i użytkowania, obecność zabezpieczeń przed niepożądanym otwarciem oraz obecność informacji wpływających na bezpieczeństwo użytkownika (np. data przydatności do spożycia, ostrzeżenie o występowaniu alergenów). Z kolei do grupy cech o średniej ważności $60 \%$ ankietowanych zaliczyło obecność zabezpieczeń gwarantujących pierwsze użycie (4,2 pkt) oraz bezpieczeństwo przy manipulacjach (np. podczas przenoszenia, układania) - 4,0 pkt. Ważność cechy związanej z odpornością opakowania na zagrożenia mikroklimatyczne, biotyczne i mechaniczne oceniono najniżej (3,5 pkt.), czyli $54 \%$ respondentów uznało tę cechę za mniej ważną.

\section{Wnioski}

1. Spośród cech opakowań do żywności związanych z bezpieczeństwem najistotniejszą cechą dla respondentów był brak interakcji składników materiału opakowaniowego z produktem ( $70 \%$ respondentów).

2. Do grup cech bardzo ważnych dla ankietowanych zaliczono bezpieczeństwo użytkowania.

3. Zachowanie ilości i jakości zawartości podczas przechowywania i użytkowania, obecność zabezpieczeń przed niepożądanym otwarciem oraz obecność informacji wpływających na bezpieczeństwo użytkownika były dla respondentów cechami ważnymi.

4. Do grupy cech o średniej ważności zaliczono: obecność zabezpieczeń gwarantujących pierwsze użycie oraz bezpieczeństwo przy manipulacjach.

5. Za najmniej istotną cechę opakowań respondenci uznali narażenia mikroklimatyczne, biotyczne i mechaniczne.

6. Na podstawie uzyskanych wyników badań ankietowych stwierdzono, że konsumenci i użytkownicy zwracają uwagę na bezpieczeństwo zapakowanych produktów. W zależności od stopnia świadomości, kryteriów socjodemograficznych oraz trendów panujących na rynku wymagania społeczne konsumentów wobec opakowań do żywności są zróżnicowane, uwzględniające ich indywidualne potrzeby i wymagania. 
Publikacja sfinansowana ze środków przyznanych Wydziałowi Towaroznawstwa Uniwersytetu Ekonomicznego w Krakowie w ramach dotacji na utrzymanie potencjału badawczego.

\section{Literatura}

[1] Bix L., de la Fuente J., Sundar R.P., Lockhart H.: Packaging design and development. In: The Wiley Encyclopedia of Packaging Technology. $3^{\text {rd }}$ ed. Ed. K.L. Yam. John Wiley and Sons. Hoboken, New Jersey, USA, 2009, pp. 859-866.

[2] Celhay F., Boysselle J., Cohen J.: Food packages and communication through typeface design: The exoticism of exotypes. Food Qual. Pref., 2015, 39, 167-175.

[3] Cholewa-Wójcik A.: Potrzeby i wymagania konsumentów w zakresie opakowań do żywności. Opakowanie, 2016, 5, 63-68.

[4] Cholewa-Wójcik A., Kawecka A.: Zapewnienie bezpieczeństwa i jakości opakowań w łańcuchach dostaw. W: Zarządzanie jakością: Osiągnięcia i wyzwania. Red. P. Kafel, T. Sikora. Wyd. Nauk. PTTŻ, Kraków 2015, ss. 25-35.

[5] Cierpiszewski R.: Opakowania aktywne i inteligentne. Wyd UEP, Poznań 2016.

[6] Dejnaka A. Opakowanie jako narzędzie wpływania na wybory konsumentów. Zesz. Nauk. Wyższej Szkoły Bankowej we Wrocławiu, 2011, 23, 131-143.

[7] Estiri M., Hasangholi T., Yazdani H., Nejad H.J., Rayej H.: Food products consumer behaviors: The role of packaging elements. J. Appl. Sci., 2010, 10, 535-543.

[8] Jerzyk E.: Design opakowania i jego elementy w procesie podejmowania decyzji zakupowych. [on line]. PWE. Dostęp w Internecie [3.04.2017]: http://www.pwe.com.pl/files/1276809751/file/mir 4 2014_design.pdf

[9] Kańczukowska-Stadnik A.: Wymagania producentów opakowań i detalistów wobec opakowań jednostkowych. Ważenie, Dozowanie, Pakowanie, 2008, 2, 85-92.

[10] Lisińska-Kuśnierz M.: Aspekty społeczne w opakowalnictwie. Wyd. UEK, Kraków 2010.

[11] Lisińska-Kuśnierz M.: Oczekiwania konsumentów dotyczące opakowań a realizacja ich potrzeb społeczno-ekonomicznych. Zesz. Nauk. UEK, 2011, 874, 89-100.

[12] Lisińska-Kuśnierz M.: Food packaging as non-satisfactory communication instrument in opinion of consumers. In.: Commodity Science in Research and Practice - Innovations in Product Development and Packaging. Eds. A. Cholewa-Wójcik, A. Kawecka. Polish Society of Commodity Science, Kraków 2014, pp. 141-155.

[13] Lisińska-Kuśnierz M., Kawecka A.: Attributes of food packaging safety. In: Selected Aspects of Industrial Products Quality. Eds. J. Żuchowski, R. Zieliński. Wyd. Nauk. Inst. Technol. Eksploatacji - PIB, Radom 2012, pp. 23-34.

[14] Lisińska-Kuśnierz M., Ucherek M.: Essence of holistic angle on development of consumer behaviour by packaging. Towaroznawcze Problemy Jakości, 2011, 4, 66-72.

[15] PN-EN ISO 9000:2015-10. Systemy zarządzania jakością. Podstawy i terminologia.

[16] Słownik języka polskiego. Red. L. Drabik, E. Sobol. PWN, Warszawa 2007.

[17] Solomon M., Bamossy G., Askegaard S., Hogg M.: Consumer Behavior. A European Perspective. Pearson Education Ltd, Harlow 2010.

[18] Svansen E., Vold M., Moller H., Petersen M., Larsen H., Hanssen O.: Sustainable packaging design: A holistic methodology for packaging design. Packaging Technol. Sci., 2010, 23 (3), 161-175.

[19] Tarczyńska A.S.: Projektowanie żywności wygodnej z wykorzystaniem metody QFD. Żywność. Nauka. Technologia. Jakość, 2013, 3 (88), 187-199.

[20] Technika opakowań. Red. A. Emblem, H. Emblem. Wyd. Nauk. PWN, Warszawa 2014. 
[21] Werle C.O.C., Balbo L., Caldara C., Corneille O.: Is plain food packaging plain wrong? Plain packaging increases unhealthy snack intake among males. Food Qual. Pref., 2016, 49, 168-175.

[22] Yam K.L.: Socioeconomic driving forces of food packaging. In.: The Wiley Encyclopedia of Packaging Technology. $3^{\text {rd }}$ ed. Ed. K.L. Yam. John Wiley and Sons. Hoboken, New Jersey, USA, 2009, pp. 1147-1151.

\title{
PACKAGING QUALITY AS DETERMINANT OF FOOD SAFETY IN THE CONTEXT OF SOCIAL REQUIREMENTS OF CONSUMERS
}

\author{
S u m m a ry
}

Those consumption trends that relate to the quality of food products and packaging are closely linked with the relevant requirements expressed by consumers. Social requirements of consumers on packaging can be grouped into three basic fields: safety, extending product life through properly selecting packaging, consumer communication, convenience and functionality as well as reduction of negative environmental impacts. Safety is one of the basic human needs, which should also be covered by packaging. Safe packaging should be characterized primarily by an appropriate sanitary-hygienic condition, which does not pose a risk to a packaged food product, and, also, should ensure safe use thereof. In addition, the packaging must be characterized by stable performance parameters of a certain value since the protection of packaged products depends on them.

The objective of the research study was to determine social requirements of consumers on the safety of packaged food because those requirements constitute a factor to significantly impact the quality of packaging.

The presented research results refer to the analysis of needs and requirements on food packaging; they made it possible to determine the importance hierarchy of social requirements of consumers on food packaging. It was shown that $90 \%$ of the consumers regarded safety as the most important social requirement for packaging. $75 \%$ of the consumers rated safe use as very important. $83 \%$ of the consumers deemed the following features as important: maintaining the quantity and quality of content during storage and use, protection against unwanted opening, and information contributing to user safety. Next, $60 \%$ of the consumers claimed that middlingly important to them were safeguards to ensure that a food product was used for the first time and safety while handling food products. And $54 \%$ of the respondents declared that, of all the analyzed packaging characteristics, the least important to them was a feature linked with the resistance of packaging to microclimatic, biotic and mechanical factors.

Key words: packaging quality, food safety, social requirements of consumers, food packaging 